\title{
Mass fraction of fat, protein, and their ratio in Simmental breed cows' milk
}

\author{
Mikhail Gubanov ${ }^{1,2, *}$, and Marina Chasovshchikova ${ }^{2}$ \\ ${ }^{1}$ Federal State Institutions Federal Research Centre Tyumen Scientific Centre of Siberian Branch of \\ the Russian Academy of Sciences (Tyumen Scientific Centre SB RAS), Tyumen, Russia \\ ${ }^{2}$ Federal State Budgetary General Educational Institution of Higher Education "State Agrarian \\ University of the Northern Trans-Urals", Tyumen, Russia
}

\begin{abstract}
An important role in ensuring the taste and nutritional properties of milk belongs to its chemical composition, particularly the content of fat, protein, vitamins, and minerals. Numerous studies have confirmed the hypothesis of a close relationship between the proportion of milk fat and milk protein, which ideal ration is 1.1: $1.0-1.5$ : 1.0. It is this ratio that not only ensures the harmonious taste of the product but is also an indicator of a complete balanced feeding of animals. The studies were carried out in January - March 2021 at the breeding plant of the Simmental breed in the Tyumen region. The chemical composition of milk was determined in the laboratory for selection control of milk quality of the FSBEI of Higher Education "SAU of the Northern Trans-Urals". The ratio between the mass fraction of fat and mass fraction of protein on average for the first three months of 2021 can be considered stable. In the milk of $20.0-27.8 \%$ of cows, there was a shift in equilibrium towards a decrease in butterfat content between the mass fraction of fat and mass fraction of protein, in turn, an increase in butterfat content relative to protein was noted in milk of $2.1-3.0 \%$ of cows. Equilibrium shift between butterfat and protein over 1.5: 1.0 suggests the risk of ketosis in the herd. In this regard, we recommend carrying out additional diagnostics on the content of ketone bodies in the blood and urine of cows during the milking period to confirm the presumptive diagnosis.
\end{abstract}

\section{Introduction}

The competitiveness and profitability of the livestock industry directly depends on the volume and quality of milk that meets all modern global criteria for its safety. Improving the beneficial properties of milk, its natural value for human nutrition, minimizing losses caused by an insufficiently thought-out technology of keeping, feeding, and milking of animals can be attributed to the most urgent aspects that make it possible to ensure the food security of the Russian Federation considering the ambiguous political and economic situation caused by sanctions from foreign countries and completely cover the population's need for this useful product [1-4].

\footnotetext{
*Corresponding author: mv.gubanov@abc.tsaa.ru
} 
An important role in ensuring the taste and nutritional properties of milk belongs to its chemical composition, particularly the content of fat, protein, vitamins, and minerals. Numerous studies have confirmed the hypothesis of a close relationship between the proportion of milk fat and milk protein, which ideal ration is $1.1: 1.0-1.5: 1.0$. It is this ratio that not only ensures the harmonious taste of the product but is also an indicator of a complete balanced feeding of animals. Thus, a high fat content in milk with a ratio to protein of more than 1.5: 1.0 indicates a critically high level of body fat reserves' consumption. Combined with an energy deficit, which can be signaled by low protein levels in milk, this situation is more likely to lead to ketosis. The inverse ratio indicates the scarcity of structured feed in the diet with an abundance of concentrates [5-8].

It is for this reason that the study of milk composition and total milk productivity is an urgent problem of an applied nature [9-10].

The purpose of the work was to conduct a study and a comparative analysis of the mass fractions of fat, protein, and their ratio in the milk of Simmental cows of different ages and lactation periods.

\section{Materials and methods}

The studies were carried out in January - March 2021 in a breeding plant for breeding cattle of the Simmental breed in the Tyumen region.

The assessment of the chemical milk composition obtained on the control milking days was carried out in the laboratory for the quality of agricultural products (laboratory for selection control of milk quality of the FSBEI of HE "SAU of Northern Trans-Urals").

Indicators of the chemical composition of milk - mass fraction of fat (MF) and mass fraction of total protein (MP), were studied using a combined system of milk analyzers Bentley FTS-400.

Bentley FTS-400 is an analyzer consisting of an optical unit (an infra-red radiator, a monochromator with a turret of interference filters, a photodetector, optical components, a cuvet), an electronics unit, a homogenizer, and a computer. The principle of the analyzer's operation is based on measuring the radiation intensity in the mid-IR range of the spectrum passed through a cuvet with a homogenized test milk sample.

For control milking, the farm has individual milk meters that meet ICAR requirements. Using the software, the primary zootechnical data for each cow (inventory number, age, ordinal day of lactation, daily milk yield) was uploaded to the "Milk Laboratory" Service of LLC Regional Information Support for Pedigree Livestock Breeding of the Leningrad Region PLINOR. The results of milk analysis from the Bentley FTS-400 device were also uploaded in the program; full information on each animal is communicated in the "Milk Laboratory" Service. To conduct research on the chemical milk composition, the controlled livestock of cows of different ages and lactation stages amounted to 545 heads in January, 516 in February and 613 in March. The ratio between the mass fraction of fat and protein was determined by dividing MF by MP for each cow individually. Milk analysis results were processed biometrically using Microsoft Excel software.

\section{Results and discussion}

According to the data on the chemical milk composition and the daily milk yield on the day of control milking, a graph was built showing the productivity dynamics (Fig. 1). 


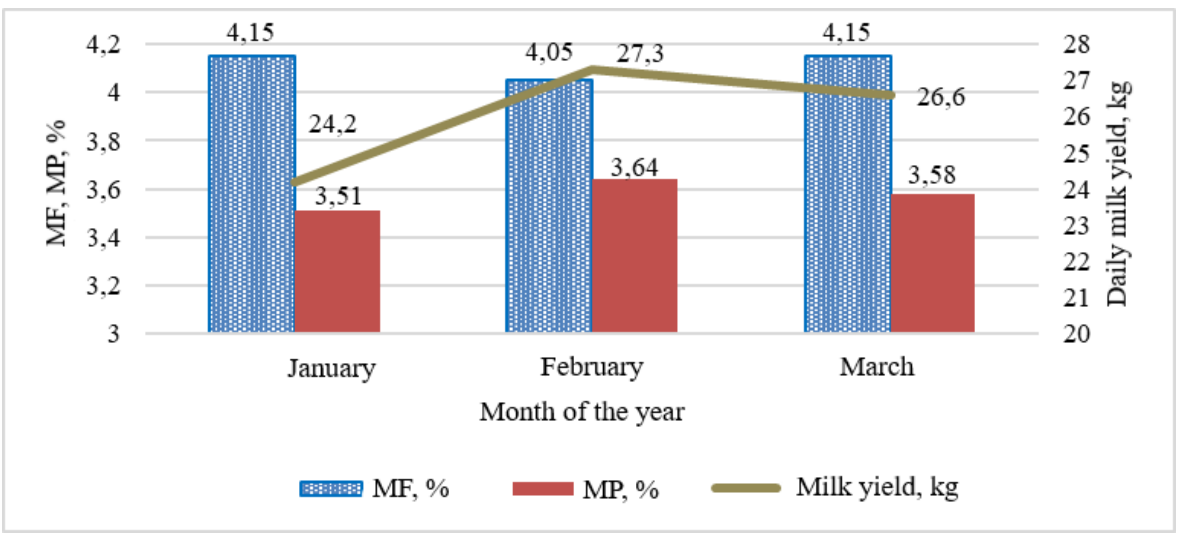

Fig. 1. Dynamics of daily milk yield, mass fraction of fat and protein by months of the 1 st quarter of 2021.

Compared to January, there was a positive dynamic of change in the daily milk yield in February - an increase of $3.1 \mathrm{~kg}$ or $12.8 \%$, in March - $2.4 \mathrm{~kg}$ or $9.9 \%$. Compared to February, there was a slight decrease in daily milk yield by $0.7 \mathrm{~kg}$ or $2.6 \%$ in March.

The average mass fractions of fat and protein for all control periods were at a high level - not less than $4.05 \%$ and $3.51 \%$, respectively. In February, there was a decrease in the mass fraction of fat by $0.10 \%$ against the background of milk yield increase, but an increase in milk protein content by 0.13 and $0.06 \%$ compared to the last months.

The ratio between the mass fraction of fat and protein on average in the herd on the control day was normal: January - 1.18, February - 1.11, March - 1.16. But the minimum and maximum values of the ratios according to the data of individual control went beyond the optimal: January - from 0.56 to 2.02; February - from 0.52 to 2.74 and March - from 0.50 to 2.47 . A shift in the balance between the mass fraction of fat and protein towards an increase (more than 1.5) is an indirect sign of ketosis, and towards a decrease (less than 1.0) - acidosis. Thus, there is a risk of both acidosis and ketosis in the controlled herd. If we pay attention to the dynamics of the shift, it is noticeable that February was the most critical month.

Daily milk yield, mass fractions of fat, protein, as well as the ratio between fat and protein were analyzed in relation to the age of cows in lactation. Table 1 provides information for January and March.

From January to March, milk yields increased in all groups of cows; this happened against the background of a decrease in butterfat content (except for full-grown) and an increase in milk protein content.

Table 1. Milk yield and milk composition of cows of different ages, $\bar{x} \pm S_{\bar{x}}$.

\begin{tabular}{|c|c|c|c|c|c|c|}
\hline \multirow{2}{*}{ Indicator } & \multicolumn{2}{|c|}{ First heifers } & \multicolumn{2}{c|}{ 2nd lactation } & \multicolumn{2}{c|}{ 3 and over } \\
\cline { 2 - 7 } & January & March & January & March & January & March \\
\hline Heads & 135 & 130 & 129 & 139 & 264 & 299 \\
\hline $\begin{array}{c}\text { Lactation day, } \\
\text { average }\end{array}$ & $204 \pm 9.4$ & $221 \pm 9.9$ & $179 \pm 12.0$ & $181 \pm 10.7 *$ & $163 \pm 6.0 * *$ & $172 \pm 6.0 * *$ \\
\hline $\begin{array}{c}\text { Daily milk } \\
\text { yield, kg }\end{array}$ & $21.6 \pm 0.71$ & $23.4 \pm 0.86$ & $24.8 \pm 0.91 *$ & $27.6 \pm 0.94 * *$ & $25.8 \pm 0.64 * *$ & $28.1 \pm 0.74 * *$ \\
\hline MF, \% & $4.21 \pm 0.07$ & $4.19 \pm 0.065$ & $4.10 \pm 0.073$ & $4.02 \pm 0.069$ & $4.15 \pm 0.040$ & $4.19 \pm 0.046$ \\
\hline MP, \% & $3.55 \pm 0.03$ & $3.62 \pm 0.025$ & $3.52 \pm 0.030$ & $3.58 \pm 0.018$ & $3.50 \pm 0.019$ & $3.57 \pm 0.016$ \\
\hline MF/MP & $1.18 \pm 0.02$ & $1.16 \pm 0.17$ & $1.16 \pm 0.018$ & $1.12 \pm 0.026$ & $1.19 \pm 0.011$ & $1.17 \pm 0.012$ \\
\hline
\end{tabular}

Note: * $\mathrm{P}>0, .99 ; * * \mathrm{P}>0.999$ compared to first heifers 
Full-age cows were characterized by the highest daily milk yield. Compared to first heifers, the advantage was $4.2 \mathrm{~kg}(\mathrm{P}>0.999)$ and $4.7 \mathrm{~kg}$ ( $\mathrm{P}>0.999)$, compared to second lactation cows -1.0 and $0.5 \mathrm{~kg}$ in January and March, respectively. In turn, first heifers were distinguished by the greatest (and older cows - comparatively lowest) mass fraction of protein and fat in milk both in January and March, but such differences can be regarded as a trend due to statistical uncertainty. The differences between the groups were $0.05 \%$ in terms of protein milk content and $0.06 \%$ in terms of butterfat content. The average ratio between the mass fraction of fat and mass fraction of protein can be considered as stable. In all age groups of cows, they were within the normative range; but once again, it should be noted that the individual control values show a wide range of limits against the background of protein or fat levels' growth. Even though there were practically no differences between the groups of cows in the average ratios of nutrients, the widest range of limits was noted among full-grown cows with the greatest shift observed towards the maximum - 2.02 in January and 2.47 in March. Thus, full-grown cows are at greater risk of ketosis than younger cows. But in general, the proportion of cows with indirect signs of ketosis was insignificant and amounted to 3.0 and $2.1 \%$ of which 1.4 and $0.9 \%$ were fullgrown cows in January and March, respectively.

The dynamics of first heifers' milk yield by days of lactation showed peak values from 30 to 99 days (Fig. 2), at the same time there was a decrease in the mass fraction of fat and protein to a minimum (Fig. 5 and 8 ).

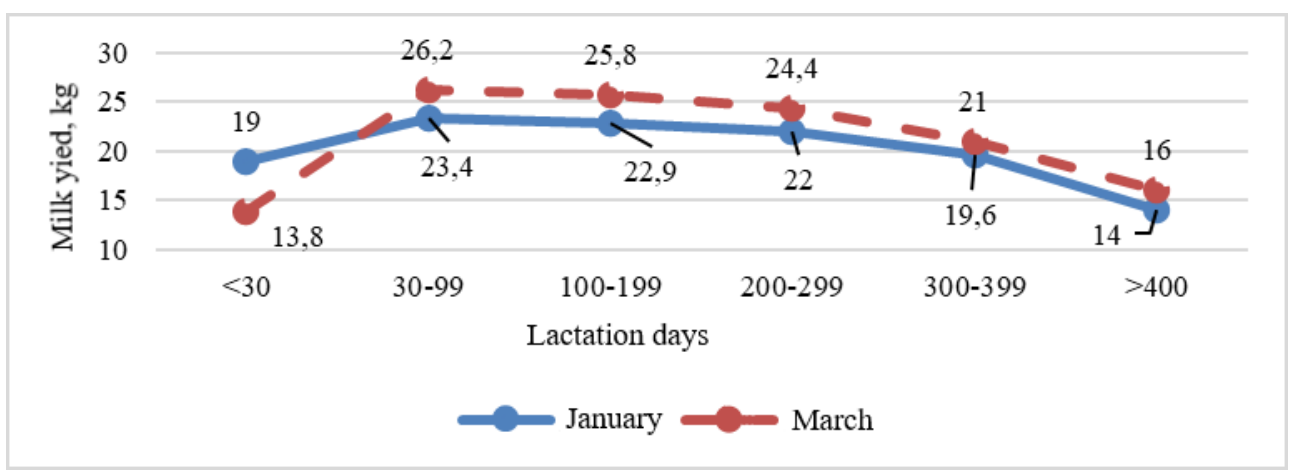

Fig. 2. Dynamics of first heifers' daily milk yield by days of lactation.

Similar changes in productivity are also typical for older cows (Fig. 3, 4, 6, 7, 9, 10). In cows of second and full-grown lactations, as compared to first heifers, a less stable type of lactation curve is noticeable, while maintaining the general tendency to reduce milk yield and increase the mass fraction of fat and protein by the end of lactation. So, the first heifers' daily milk yield in the last analyzed period is $60-61 \%$ of the milk yield at the peak, then in second lactation cows - $42-44 \%$, and in full-grown ones - $24-35 \%$. 


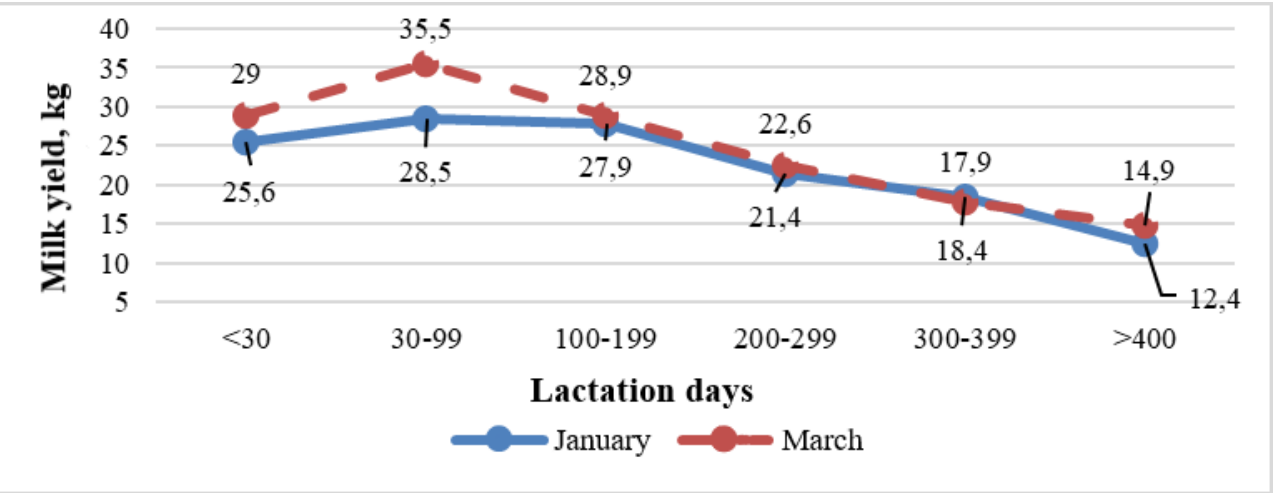

Fig. 3. Milk yield dynamics of second lactation cows by lactation days.

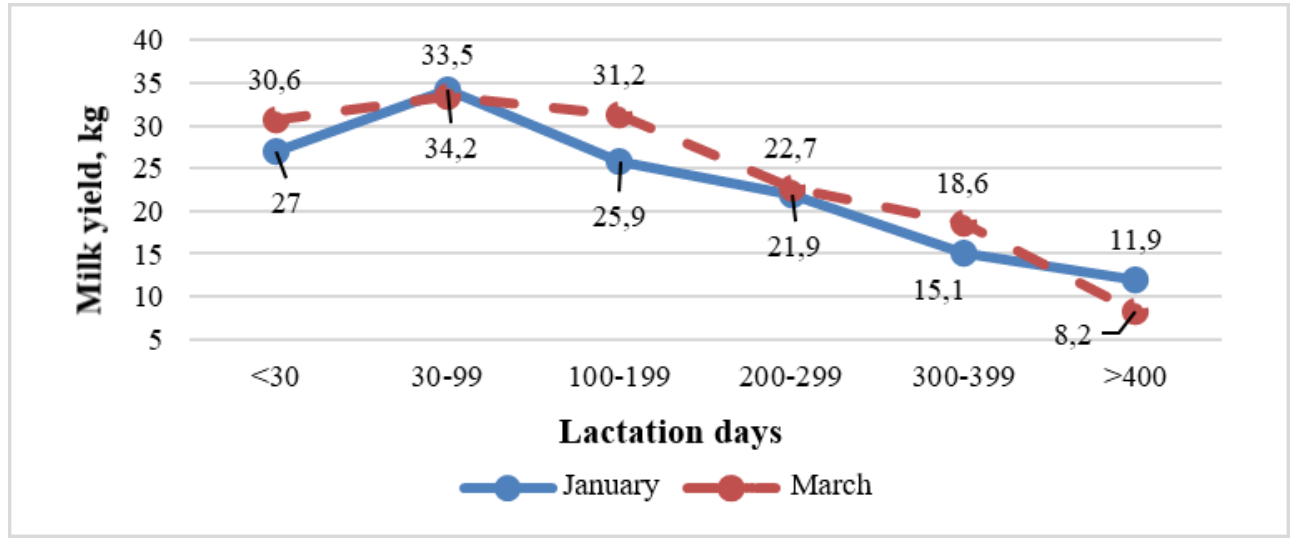

Fig. 4. Dynamics of full-grown cows' milk yield by days of lactation.

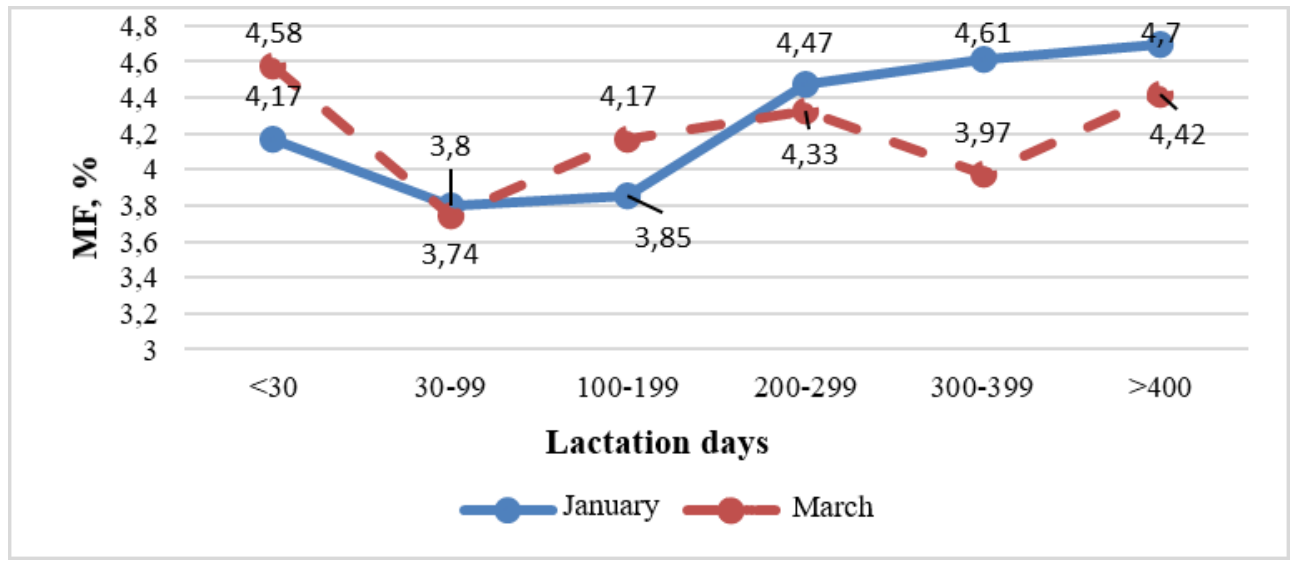

Fig. 5. Dynamics of the mass fraction of fat in first heifers' milk by days of lactation. 


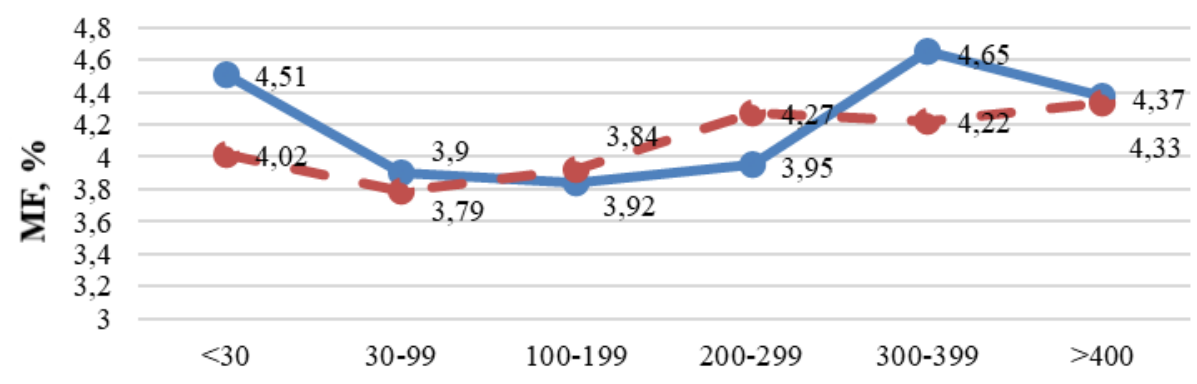

Lactation days

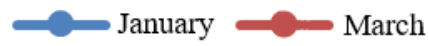

Fig. 6. Dynamics of the mass fraction of fat in the milk of second lactation cows by days of lactation.

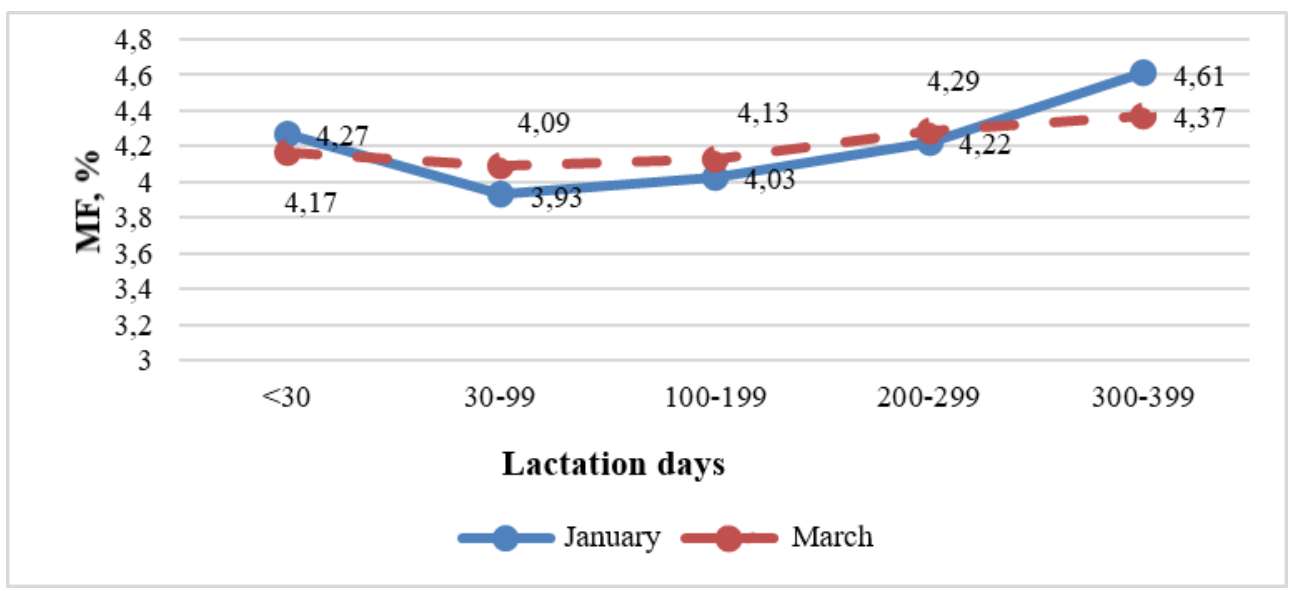

Fig. 7. Dynamics of the mass fraction of fat in the full-grown cows' milk by days of lactation

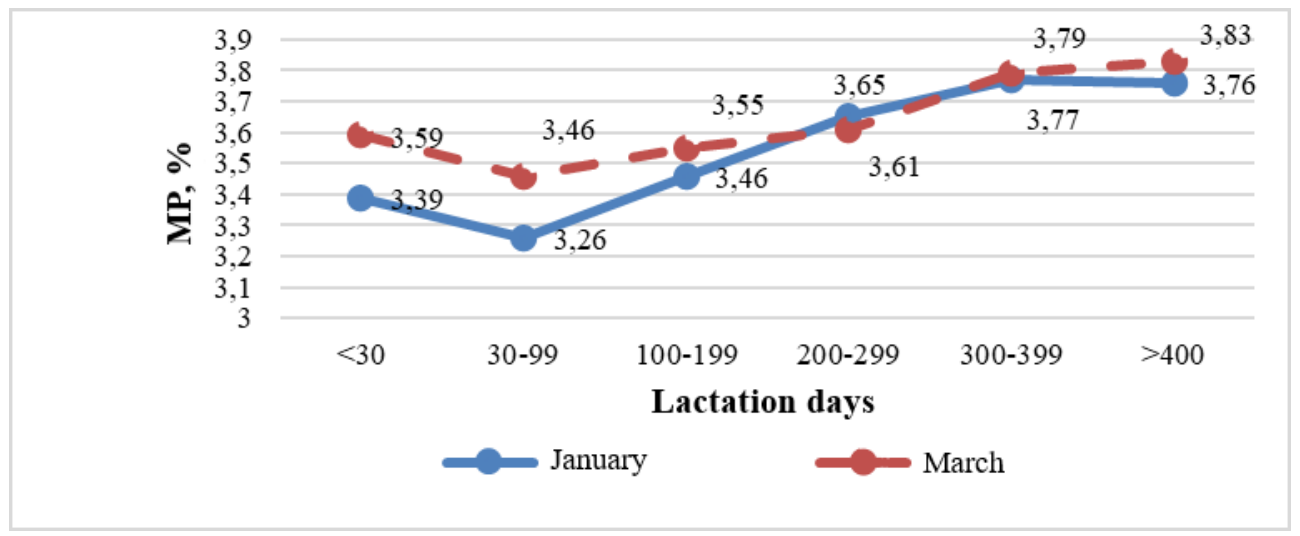

Fig. 8. Dynamics of the mass fraction of protein in the first heifers' milk by days of lactation 

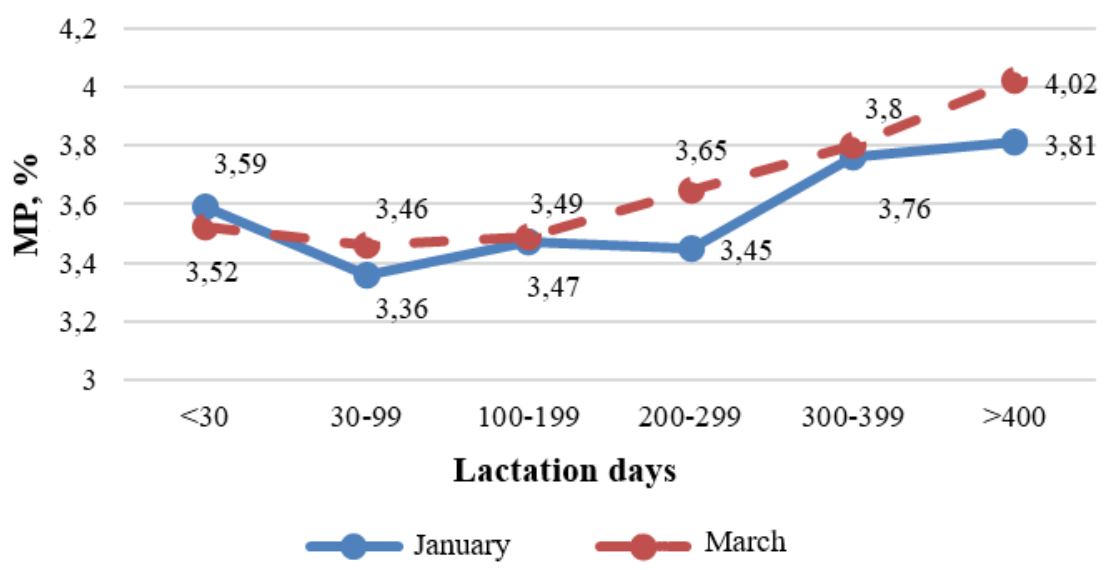

Fig. 9. Dynamics of the mass fraction of protein in the milk of second lactation cows by days of lactation

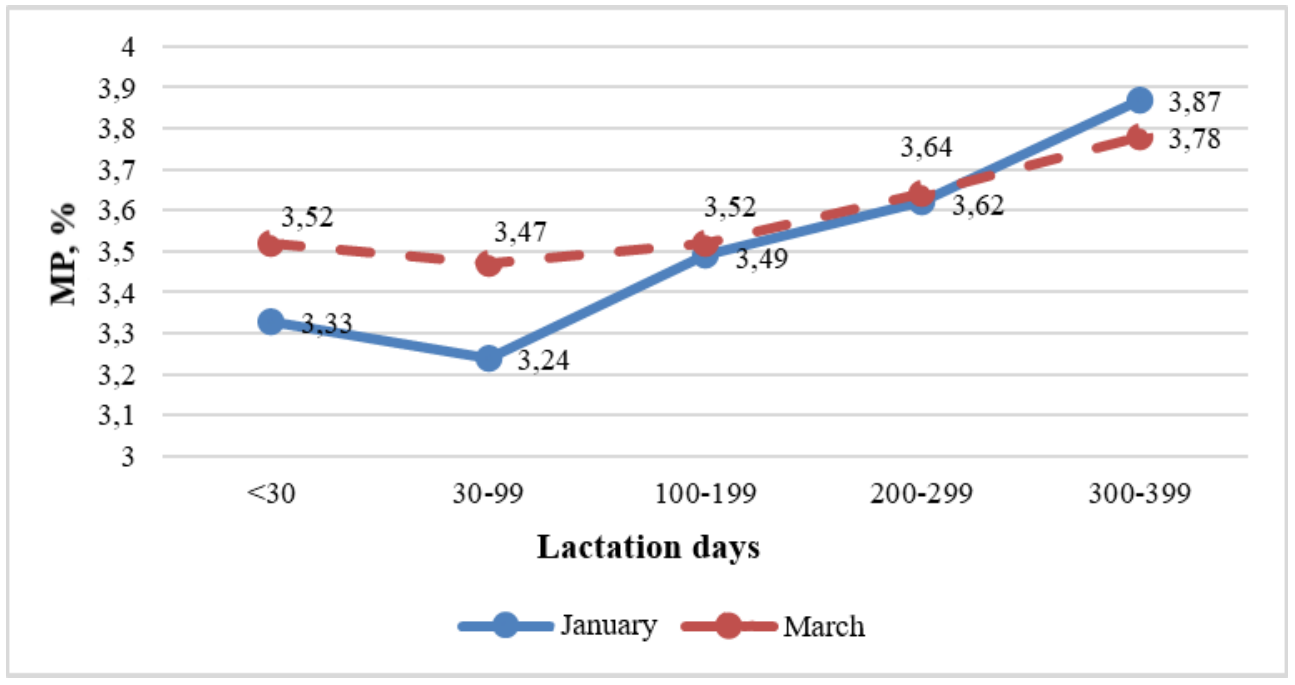

Fig. 10. Dynamics of the mass fraction of protein in full-grown cows' milk by days of lactation

The ratio between the mass fraction of fat and protein in first heifers changed during lactation, which is especially noticeable in March during the period of 30-99 and 300-399 days of lactation, when the ratio shifts to one (Fig. 11). 


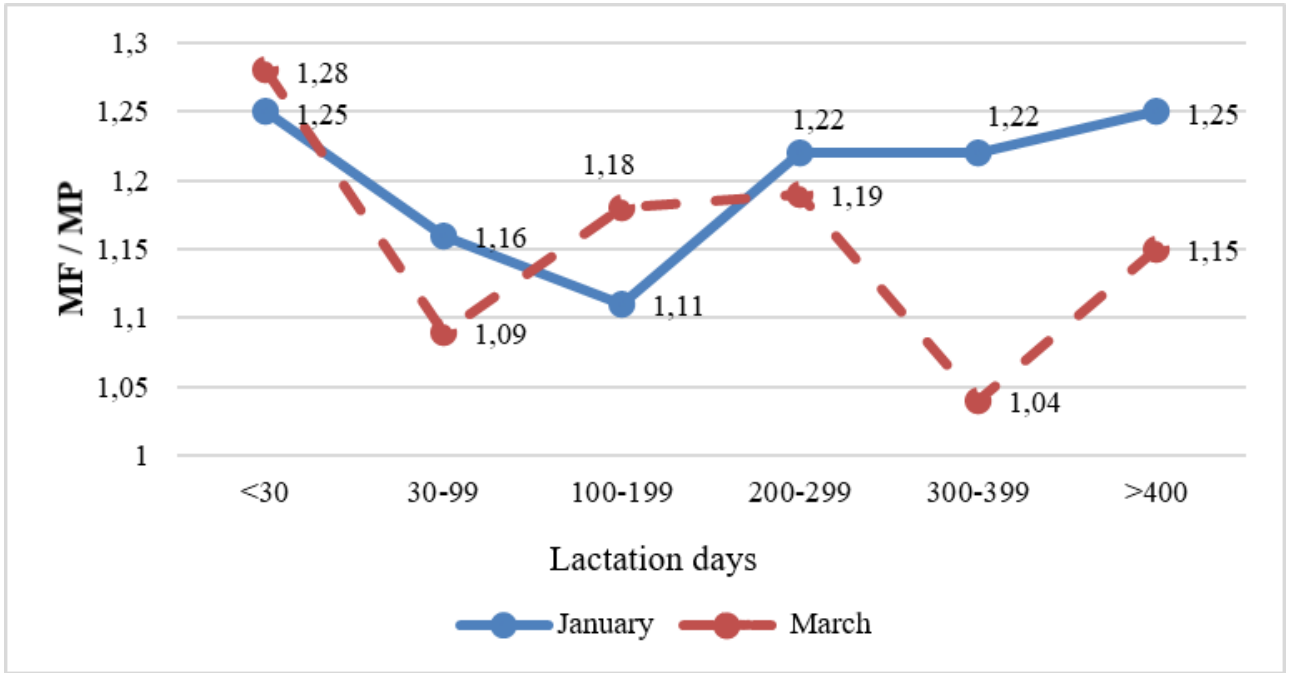

Fig. 11. Dynamics of the MF/MP ratio in first heifers' milk by days of lactation

In the group of second lactation cows, the average March values in the period from 30 to 99 and from 300 days are also close to the critical point (Fig. 12).

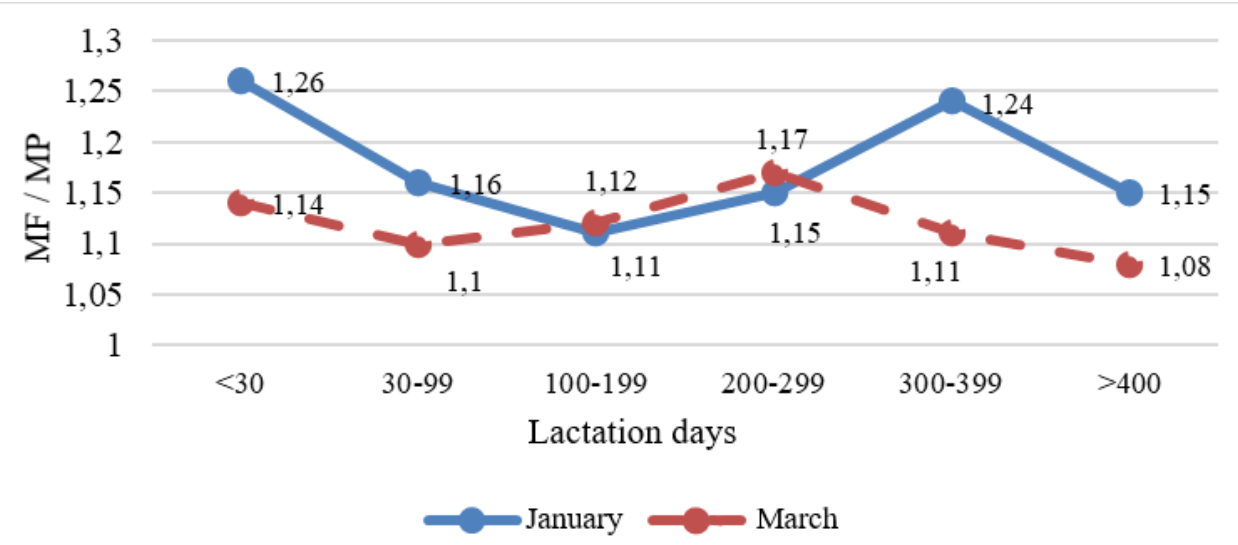

Fig. 12. Dynamics of the MF/MP ratio in the milk of second lactation cows by days of lactation.

In full-grown cows, the average ratio between the mass fraction of fat and protein is more stable (Fig. 13) than in younger cows. 


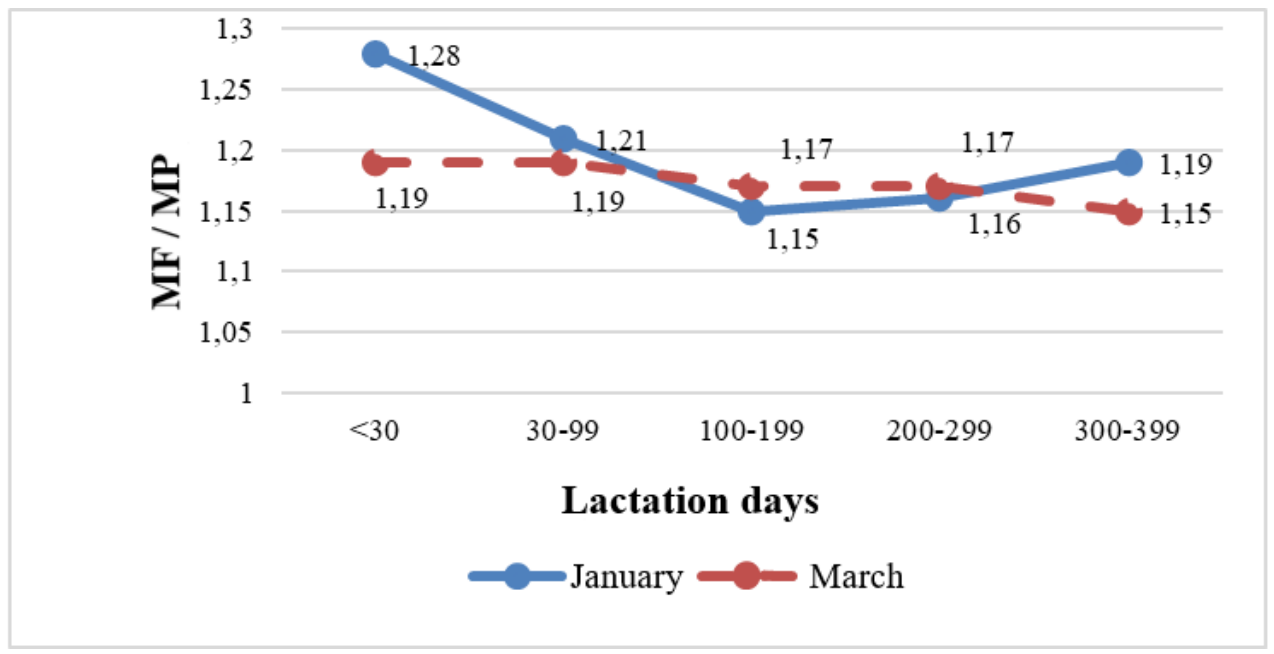

Fig. 13. Dynamics of the MF/MP ratio in milk of full-grown cows by days of lactation

So, judging by the average values of the controlled ratios, the Simmental cows more often showed a shift towards a decrease in fat content in relation to protein. Thus, the share of cows with the indicated traits was 20.0 and $27.8 \%$ of the total surveyed livestock in January and March, respectively. Most often, these disorders were manifested in young cows at the peak of productivity - 30 - 99 days and at the end of lactation. At the beginning of lactation, such changes could occur against the background of highly concentrated diets, which are characterized by an excess of starch, sugar, and a deficiency of long-fiber cellulose. It is known that feeding starchy fodder increases the formation of propionic acid, and a lack of fiber leads to insufficient formation of acetic acid, which ultimately increases the milk protein content, but reduces the mass fraction of fat. At the end of lactation, a significant increase in the mass fraction of protein in the first heifers' milk could be due to an excess of metabolic energy in the diet.

\section{Conclusion}

For the first three months of 2021 in the breeding plant of the Simmental breed of the Tyumen region, the highest daily milk yield was observed in February - $27.3 \mathrm{~kg}$ of milk with a mass fraction of fat and protein of 4.05 and 3.64\%. Compared to January, in February there was an increase in milk yield of $3.1 \mathrm{~kg}$ or $12.8 \%$, in March $-2.4 \mathrm{~kg}$ or $9.9 \%$. Compared to February, there was a slight decrease in daily milk yield by $0.7 \mathrm{~kg}$ or $2.6 \%$ in March. The ratio between the mass fraction of fat and protein on average in the herd on the control day was normal: January -1.18 , February -1.11 , March -1.16 . The minimum and maximum values of the ratios went beyond the recommended ranges: January - from 0.56 to 2.02; February - from 0.52 to 2.74 , March - from 0.50 to 2.47 .

Full-grown cows were characterized by the highest daily milk yield. Compared to first heifers, the advantage was $4.2 \mathrm{~kg}$ ( $\mathrm{P}>0.999)$ and $4.7 \mathrm{~kg}(\mathrm{P}>0.999)$, compared to second lactation cows -1.0 and $0.5 \mathrm{~kg}$ in January and March, respectively. There were no significant differences in the mass fraction of fat and protein between the groups of cows of different ages.

The dynamics of daily milk yield by days of lactation showed the highest values in the period from 30 to 99 days of lactation, at the same time, a decrease in the mass fraction of fat and protein in milk was observed. The lactation curve of first heifers was more stable than that of older cows. 
There was a shift in equilibrium towards a decrease in butterfat content between the mass fraction of fat and mass fraction of protein in the milk of $20.0-27.8 \%$ of cows; in milk of $2.1-3.0 \%$ of cows, on the contrary, -towards an increase in butterfat content relative to protein. A shift in the equilibrium between milk fat and protein by more than 1.5: 1.0 suggests the risk of ketosis in the herd. In this regard, we recommend carrying out additional diagnostics on the content of ketone bodies in the blood and urine of cows during the milking period to confirm the presumptive diagnosis. The reverse shift is more often seen among young cows at their peak of productivity. Such a clinical picture is often observed with an excess of carbohydrate feed in the diet, against the background of a lack of fiber, which leads to acidosis in cows. In this regard, based on the control milking analysis results, we recommend conducting a survey of the cows' health with a shift in the equilibrium between fat and protein in milk to clarify the reasons for these changes.

\section{References}

1. A.A. Bakharev, O.M. Sheveleva, K.A. Fomintsevetal., J. Pharm. Sci. \& Res. 10(9), 2383-2390 (2018)

2. A.V. Garkovenko, V.V. Radchenko, E.V. Ilnitskaya et al., J. of Pharmac. Sci.andRes. 10(6), 1545-1551 (2018)

3. J.A. Tkacheva, L.A. Glazunova, D.V. Dubrovin and Y.V. Glazunov, EurAsian J. of BioSci., 13, 1357-1361 (2019)

4. A.A. Bakharev, O.M. Sheveleva, M.A. Chasovshchikova et al., IOP Conference Series: Earth and Environmental Science, 012097 (2021)

5. V.N. Domatsky, A.A. Antimirova, Y.V. Glazunov and L.A. Glazunova, IndoAmer. J. of pharmac. Sci. 06(07), 13900-13905 (2019)

6. M.A. Chasovschikova, O.M. Sheveleva, M.A. Svjazhenina et al., Journal of Pharmaceutical Sciences and Research, 7(9),1038-1044 (2017)

7. O.A. Zavyalov, A.V. Kharlamov, V.A. Kharlamov and V.G. Litovchenko, Bull. of meat cattle breed 3(81), 68-72 (2013)

8. Y.V. Glazunov and L.A. Glazunova, Indian Veterin. J. 95(1), 19-22 (2018)

9. O.M. Sheveleva, A.A. Bakharev and S.F. Sukhanova, IOP Conf. Ser.: Earth and Environmental Sci. 341, 012023 (2019) DOI: 10.1088/1755-1315/341/1/012023.

10. Y.V. Glazunov and L.A. Glazunova, J. of Pharmac. Sci. and Res. 10(1), 129-131 (2018) 